\title{
THE CURRENT STATE, PROBLEMS AND PROSPECTS OF MASTER'S DEGREE PROGRAMS IN SPEECH-LANGUAGE PATHOLOGY IN RUSSIA
}

\author{
Dr. Anna A. Almazova, Prof. Yulia O. Filatova, Irina V. Novitskaia \\ Moscow Pedagogical State University (Russia)
}

\begin{abstract}
The article discusses the current state, problems and prospects of Master's degree programs in speech-language pathology in Russia. Authors carry out a theoretical overview and comparative analysis of the literature on Master training programs of logopedics or speech-language therapists and define two large groups of programs available in Russian universities, depending on their orientation towards training a speech-language therapist graduate. Particular attention is given to the problems stated in the names of the training programs and how this reflects various aspects that determine the functioning of the speech-language pathology system in the Russian Federation. The article also provides a brief historical background on the training of speech-language therapists and gives an outline of the current state and prospects of Master training in speech-language pathology at the Moscow Pedagogical State University.

Keywords: training of logopedics; master's degree programs; speech-language therapist (SLT); education; healthcare; analysis
\end{abstract}

\section{Introduction}

Both Russian scientific research and foreign studies view logopedics or speech-language pathology (SLP) as an area of scientific knowledge and a field of professional activity that has an interdisciplinary context, which is based on the integration of clinical, pedagogical, psychological and linguistic data (Almazova Orlova 2017; Artemova Artemova Tishina Boryakova \& Kurtanova 2021; Czaplewska Milewski 2014; Filatova 2008; Georgieva Stoilova 2021; Georgieva Wozniak Topbash Vitaskova Vukovic Zemva \& Duranovic 2014; Orlikoff Georgieva 2021 , etc.). The emphasis is placed on linguistics, medicine and psychology as the basis for the methodological and pragmatic aspects of SLP with pedagogy determining the technological component. The Russian scientific and professional community recognises that logopedics operates with pedagogical methods in 
the system of special education for children with special educational needs, and adults with speech impairments. This determines the field of training of speechlanguage therapists (SLTs) in universities, which, in accordance with the Federal State Educational Standard of Higher Education, is found in Russian Federation withing the scope of "Education and Pedagogical Sciences" (Order of the Ministry of Education and Science of the Russian Federation of February 22, $2018 \mathrm{~N} 121$ "On the Approval of the Federal State Educational Standard of Higher Education Bachelor's degree, education program 44.03.01 Pedagogical Education”, Order of the Ministry of Education and Science of the Russian Federation of February 22, 2018 N 126" On the Approval of the Federal State Educational Standard of Higher Education - Master's degree, education program 44.04.01 "Pedagogical education").

It is known that the content of pedagogical education is the basis of the professional culture of a teacher, which remains valid for a SLT-teacher. The organization of the multivariate educational space of the higher pedagogical school includes an optimal list of ideas, methods of cognition and thinking, which will allow the teacher to become an entity involved in professional activity in the future, widely using self-development and self-education strategies. According to Slastenin (2000), the content aspect of teacher training program should be based on the principles of universality, integration, comprehensiveness of the picture of the world, recreated by a set of basic disciplines, fundamentality, professionalism, variability and multilevel training.

This approach is decisive for the development, modernization and improvement of training programs for SLTs in the context of the dominant strategies in the modern world of personality-oriented transformation of vocational education. In this regard, a future SLT appears as a specialist (Bachelor's or Master's degree level), possessing a set of personal, cognitive, professional and activity competencies and qualities, capable of self-development and professional growth. At the same time, in the modern paradigm of education, SLP is presented as an anthropocentric science focused on solving the communicative, social, psychological problems of an individual with speech \& language disorders (Almazova 2019).

However, the professional activity of a SLT largely depends on the institutional conditions for its implementation. In the presence of the unity of the target setting, which in general terms in the Russian education and health care systems can be represented as "normalization of speech activity", there are different legal, organizational, substantive conditions for the work of specialists.

These differences are amplified in the development of the systems themselves. In one case, the development and implementation of adapted educational programs for all categories of children with special educational needs and special education teachers (including SLTs) are included in their implementation, ensuring the development of life and academic competencies by students. In another case (in the 
health care system), habilitation and rehabilitation systems for children, adolescents and adults are actively developing, which is not least due to the introduction of the International Classification of Functioning, Disabilities and Health (ICF) (World Health Organization 2001). Here a SLT joins an interdisciplinary team of specialists, ensuring the development/restoration of speech and communication functions. This differentiation affects the definition of the range of training programs for specialists, including master's degree programs.

In accordance with the Russian Educational Standard, a holder of master's degree in SLP is trained to solve problems in the field of intervention and education, diagnostics and prevention, research, teaching, organization and management, cultural and educational activities (Order of the Ministry of Education and Science of the Russian Federation of February 222018 N 126 "On Approval of the Federal State Educational Standard of Higher Education - Master's degree, education program 44.04.01 "Pedagogical Education"). This is ensured by the formation of professional competence in the process of university training, including communicative, informational, regulatory, operational and other components.

This complexity and multidimensional nature of the construct determines the need and demand for master's degree programs that are variable in terms of specific targets and content, in which the SLP component is presented in different ways.

\section{Purpose of the Study}

This article discusses the current state, problems and prospects of SLP master's degree programs in Russia.

\section{Comparative Analysis of SLP Master's Degree Programs in Russia}

A theoretical overview and comparative analysis of the literature on SLP master's training programs in Russia shows that the set of programs that provide Logopedics training in Russian universities falls into two large groups, depending on their orientation towards training a SLT graduate:

Group I - comprehensive training programs for master's degrees in special education aimed at acquiring competencies in interdisciplinary fields of science and practice, where logopedics is one of the sections presented to a greater or lesser extent (e.g., "Modern Technologies of Inclusive Education" - Tambov State University named after G. R. Derzhavin, "Psychological and Pedagogical Support of Persons with Disabilities" - Perm State Humanitarian and Pedagogical University, etc.);

Group II - master's degree programs in Logopedics, aimed at deepening and/or specializing professional competencies in SLP compared with the bachelor's level (e.g., "Comprehensive Support for the Education of Persons with Speech-Language Impairments" - Belgorod State University; "Clinical Logopedics" - Southern Federal University). 
The ratio of the designated groups of programs is shown in Figure 1.

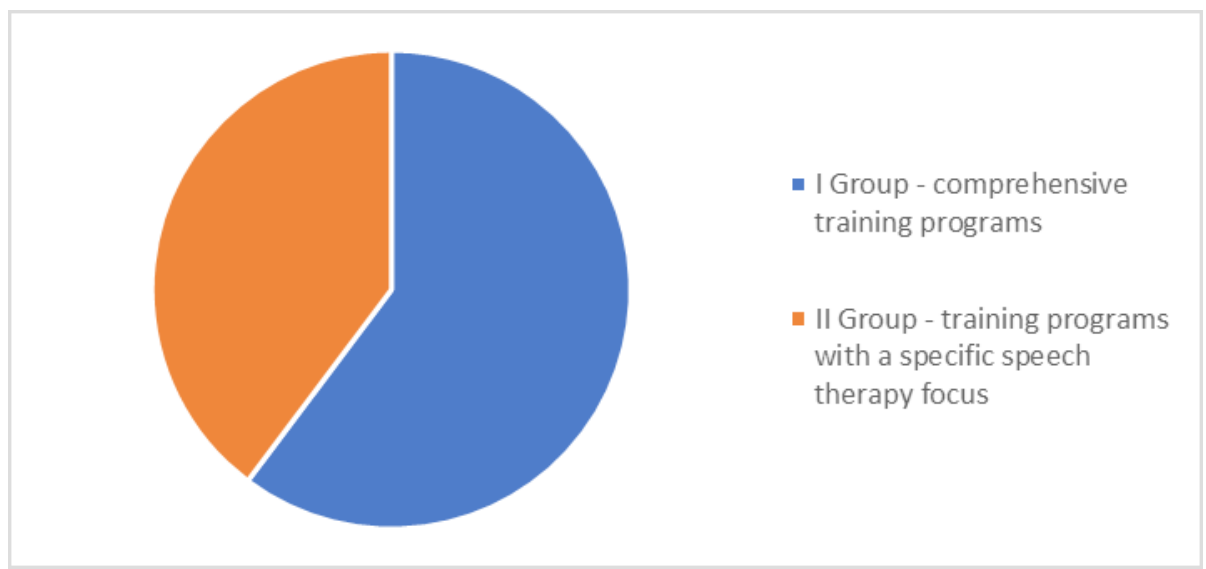

Figure 1. The ratio of SLP orientation of master's degree programs in the Russian Federation

The analysis of open data indicates that 38 universities of the Russian Federation implement master's degree programs in special education, 23 of which implement programs with a specific SLP focus (exclusively or in a package with other programs).

The largest number of universities implement comprehensive training programs (Group I). At the same time, graduates usually choose to work in the education system, rather than in the health care system. Universities offer training mainly in the field of curative education, psychological and pedagogical support and rehabilitation of children with special needs, within which students also study a number of disciplines with a SLP focus. These training programs involve full-time and parttime forms of study for 2 and 2.5 years accordingly. Within the framework of these programs, students master the disciplines of the basic and variable part, are engaged in research work (planning, conducting research, public defence of a thesis), and also undergo scientific and pedagogical, research and teaching practical training to obtain professional skills and professional experience, as well as undergraduate practice. In some cases, it is possible to speak about the regional specifics of the training program e.g., "Psychological and Pedagogical Support of Inclusive Education in the Arctic Region" (Northern (Arctic) Federal University named after M.V. Lomonosov) or about emphasise placed on a specific age category e.g., "Early Comprehensive Assistance to Children with Developmental Disabilities" (Moscow City University).

Special attention should be paid to specialized programs focused on the training of a SLT (Group II). Mastering such programs gives graduates a number of advantages in finding employment for relevant positions (SLT-teacher, SLT). 
The problems stated in the names of the training programs can be considered in relation to various aspects that determine the functioning of the SLP system in the Russian Federation. In particular, the following groups of programs are clearly distinguished:

1) general training programs, without specifying aspects of training and future professional activity (e.g., "Logopedics" - North Caucasus Federal University; "Logopedics Technologies for Overcoming Speech-Language Disorders" Novosibirsk State Pedagogical University);

2) training programs focused on the graduate's work in certain institutional conditions; predominantly (but not always) this is the way in which training programs of clinical orientation are declared (e.g., "Clinical Logopedics with the Basics of Neuroscience in Special Education" - Stavropol State Medical University; "SLP in the Education and Health Care System" - Leningrad State University named after A.S. Pushkin);

3) training programs focused on working with persons of a certain age, i.e., children (e.g., "Preschool Logopedics" - Nizhny Novgorod State Pedagogical University named after Kozma Minin; "Organization of Intervention and Pedagogical Work with Children with Speech-Language Disorders" - Moscow City Psychological and Pedagogical University);

4) training programs focused on solving the important problems of professional activity (e.g., "Design and Modelling in Logopedics" - Leningrad State University named after A.S. Pushkin; "Innovations in the Theory and Practice of Logopedics" - Belgorod State National Research University);

5) specialized training programs focused on speech therapy for a specific category of people (e.g., "Aphasiology and Neurorehabilitation" - Nizhny Novgorod State Pedagogical University named after Kozma Minin).

The distribution of programs by selected groups is shown in Figure 2.

Regardless of the highlighted priority aspects, the purpose of the programs is to ensure the training of highly qualified personnel who know the theoretical and methodological foundations of SLP and special education. In general, this is the design, testing and implementation of psychological and pedagogical technologies for identifying and treating disorders in speech-language development, as well as the formation of the graduate's readiness for various types of professional activity in intervention, rehabilitation, social adaptation and general education systems. Undergraduates acquire competencies in the field of education of persons with speech-language disorders, research and design of intervention assistance programs and their resource provision, gain experience in speech therapy and monitoring its quality, and acquire knowledge in the field of neuropsychology, psycholinguistics, linguistics of children's speech, etc.

Students master various theoretical and methodological aspects of SLP, management in the intervention and education process, tutor support of a 


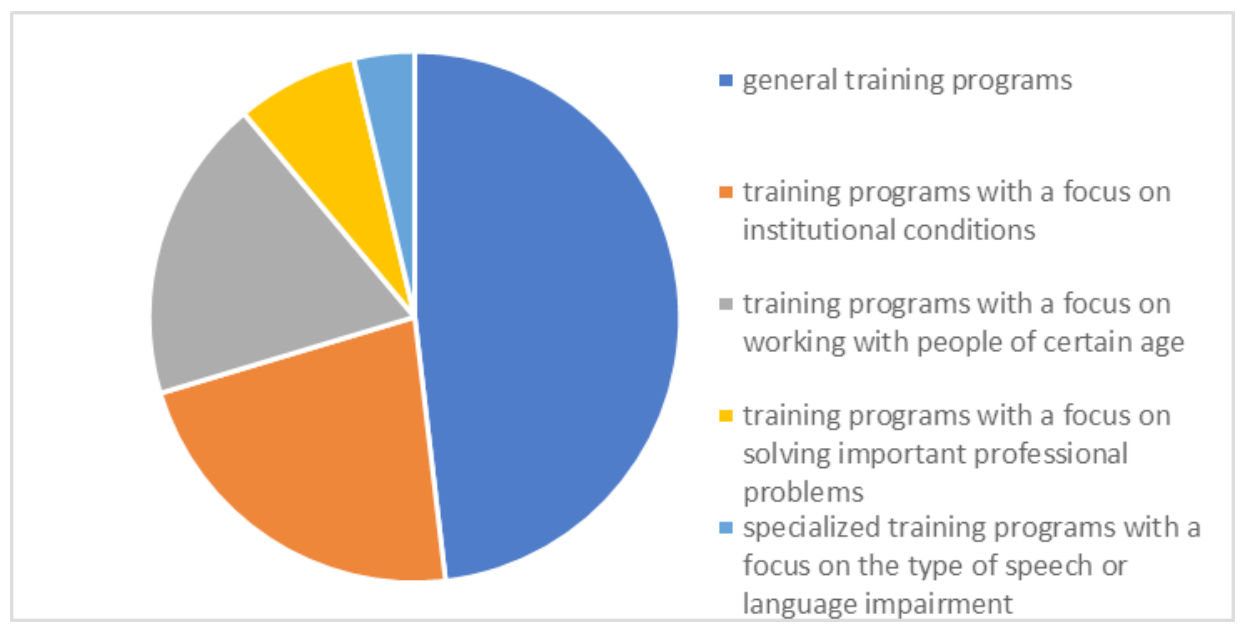

Figure 2. Groups of master's degree programs in SLP

child and his/her family in inclusive education, acquire skills in information and communication technologies in relevant for a SLT, technologies of networking and social partnership in the field of supporting persons with speech impairments, etc. In addition to the standard set of disciplines in the basic part of the curriculum, a number of highly specialized disciplines in the variable part may be offered to the students, e.g., "Actual Problems of Modern Logopedics", "SLP for Children with ASD", "Development of Communicative Skills in Early Age Children", "Ways of Overcoming Dysorthography", "Fluency Disorders", etc., as well as a number of optional disciplines that differ depending on the priorities of the developers.

In the process of mastering clinical programs of training, undergraduates acquire the basic concepts of biomedical foundations of SLP. This encompasses the scope of the subject, methods and problems of age-related neurophysiology, the structure and functions of brain systems, the dynamics of the development of the nervous system in ontogenesis, the development of neurophysiological mechanisms and anatomical structures that provide speech communication, the peculiarities of the higher nervous activity of children and adolescents in ontogenesis and dysontogenesis, clinical manifestations and methods of diagnosing speech-language disorders for the possibility of effective design and implementation of individual and group SLP programs. As part of mastering the programs, students have the opportunity to study a number of specific SLP disciplines, such as "Technologies of Treatment of Rhinolalia", "Techniques of Restorative Training of Patients after Organic Brain Damage", "Speech Correction after Cochlear Implantation", etc. 


\section{A Brief Historical Background on the Training of Logopedics at the Moscow Pedagogical State University}

At the Moscow Pedagogical State University, logopedics (speech-language therapists) have been trained for over 75 years, starting in 1946, when it became an independent field of training at the initiative of Fedor A. Rau. By this time, an awareness of the importance of studying complex and varied speech-language disorders, different in etiology, symptomatology and degree of their severity, was formed in the Soviet science. In addition to that, there was a need to train specialized personnel to help people with speech-language disorders.

The formation of the system of training logopedics is associated with the name of professor Sergey S. Lyapidevsky, who, following the clinical approach to the study of speech-language pathology, laid the foundations for an interdisciplinary interpretation of the problems of impaired speech-language development and their overcoming. In the textbook "Fundamentals of Neuropathology" (Lyapidevsky 1959), he was the first to consider the natural science foundations of special education. The period of his heading of the Logopedics department saw the creation of fundamental clinical and education ideas about etiopathogenetic mechanisms and classification of speech-language disorders. From this, the basic directions of SLP work to overcome and prevent speech-language disorders were theoretically substantiated, and later expanded by professor Lidia I. Belyakova, DMSc, who created the scientific school "Mechanisms of Speech Ontogenesis and its Disorders" during the period of her heading the Logopedics department (Almazova, Babina \& Filatova 2019).

The curricula of the training programs in SLP included and include subjects of socio-humanitarian, general pedagogical, medical, psychological, linguistic cycles, as well as special methods (Almazova, Orlova 2017). The theoretical training of students is combined with practical work in educational organizations, health care and social protection.

The modernization of higher education and the transition to a two-level training system led to the creation of the master's degree program "Project Activity in Logopedics" at the Logopedics department in Moscow Pedagogical State University (MPSU) (Babina, Belyakova \& Filatova 2008).

Design activity is one of the leading areas in the modern educational process. The complex of professional competencies formed in undergraduates was determined by the formation of readiness for the development of target guidelines for project work in professional activities, the development and implementation of the strategy and tactics of the project and monitoring of its success, analysis and presentation of research results. In general, the design of the content and technologies of work with persons with speech-language disorders is associated with the need to solving various tasks of professional activity (intervention, education, counselling and diagnostics, teaching, etc.), the possibility of designing 
and implementing SLP programs, technologies, and individual educational routes, etc. (Almazova, Babina 2018).

\section{The Current State and Prospects of Master's Degree Programs in SLP at Moscow Pedagogical State University}

Currently, the Logopedics Department at Moscow Pedagogical State University offers graduate students two master's degree training programs: "Theoretical and Applied SLP" and "Neuroscience in Special Education and Complex Rehabilitation of Persons with Communication Disorders."

The master's degree program "Theoretical and Applied SLP" is focused on providing comprehensive fundamental training of highly qualified Masters of special education, who have deep knowledge of the theoretical and methodological foundations of SLP, special pedagogy and special psychology, the ability to implement project activities, the ability to test and implement the developed SLP and, more broadly, psychological and pedagogical, technologies for diagnosing, predicting and correcting speech development disorders. The result of mastering the program is the preparation of a graduate who is ready to solve complex problems of speech therapy research, design, exposure both in standard and non-standard, changing conditions in various situations of professional activity.

The master's degree program "Neuroscience in Special Education and Complex Rehabilitation of Persons with Communication Disorders" covers the development of modern methods of including SLTs in the system of complex rehabilitation. Students master education and rehabilitation technologies of a SLT working in an interdisciplinary team of specialists. Among the sections being mastered there are technologies of personalized impact in cases of speech and communication disorders (e.g., aphasia, dysarthria, stuttering, rhinolalia, dysphonia), as well as their basic components (e.g., dysphagia). At the same time, the developers of the program rely on modern ideas and concepts for the development of rehabilitation systems (Ivanova et al. 2018). It is worth noting that the training program "Theoretical and Applied SLP" is aimed at training a SLT for work in the education system (preschool and school educational institutions) while the training program "Neuroscience in Special Education and Comprehensive Rehabilitation of Persons with Communication Disorders is focused on training an interdisciplinary team specialist in the habilitation system and rehabilitation of children, adolescents and adults, i.e. in the health care system.

\section{Conclusion}

SLP is a dynamically developing and competitive field of scientific research and professional activity in Russia. Prospects for the development of new types of SLP master's degree programs are associated with the expansion of the age range 
and the range of variability of groups in need of SLP, given the continuing aging of the population and the need for effective and high-quality SLP care throughout life. Modern type of SLP master's degree program should be both innovative and multidisciplinary, allowing students to gain a wide range of specialized clinical, pedagogical, linguistic, psychological experience so that they can become effective specialists in different institutional systems. The focus of elective disciplines can be associated with the development of the communicative culture of a SLT, the design of electronic teaching aids and multimedia support for a SLT, the development of modern approaches to the problems in ontolinguistics, the theory of speechlanguage activity, neuropsychology and other areas of scientific knowledge that are significant for SLP.

Acknowledgements. The study was carried out within the framework of the state assignment for 2021 and the planning period of 2022 and 2023 for organizations subordinate to the Ministry of Education of the Russian Federation under the project "Scientific and Methodological Substantiation and Development of New Specialized Training Programs in the Field of Training "Special Education" (order No. 281 of May 28 2021).

\section{REFERENCES}

ALMAZOVA, A.A., 2019. Vozmozhnosti realizacii antropocentrichesko go podhoda k osvoeniyu yazyka $\mathrm{v}$ sovremennoj logopedii. Nauka $i$ shkola-Science and School. 1, 78 - 83. [In Russian].

ALMAZOVA, A.A., Babina, G.V., 2018. Metodicheskie aspekty realizacii magisterskoj programmy "Proektnaya deyatel'nost' v logopedii". In: TARASOVA, O.V. (Ed.). Psychological and pedagogical support of the educational process: problems, prospects, technologies: collection of scientific papers of the participants of the $\mathrm{V}$ International scientific and practical conference (April 6-7, 2018). Eagle, 143 - 146. [In Russian].

ALMAZOVA A.A., BABINA G.V. \& FILATOVA Yu.O., 2019. Ocherk o nauchnoj shkole professora L.I. Belyakovoj. Vospitanie i obuchenie detej s narusheniyami razvitiya-Education and training of children with developmental disabilities. 1, 43 - 48. [In Russian].

ALMAZOVA, A.A., ORLOVA O.S., 2017. Iz opyta proektirovaniya i realizacii kursa lingvisticheskoj podgotovki logopedov v magistrature. Defektologiya-Defectology. 4, 57 - 66. [In Russian].

ARTEMOVA, E.E., TISHINA, L.A., BORYAKOVA, N.Yu. \& KURTANOVA, Yu.E., 2021. Aktual'nye voprosy podgotovki specialistov sluzhby psihologo-pedagogicheskogo soprovozhdeniya na urovne magistratury. Vospitanie $i$ obuchenie detej s narusheniyami razvitiya- 
Education and training of children with developmental disabilities. 2, 56-66. [In Russian].

CZAPLEWSKA, E.A. \& MILEWSKI, S., 2018. A review of SLI research in Poland. In: Almazova, A.A., Lagutina, A.V., Nabokova, L.A. \& Cherkasova, E.L. (Eds.). Specific language disorders in children: issues of diagnosis and correctional and developmental impact: Methodological collection based on the materials of the International Symposium, August 23 - 26, 2018. Moscow, 322 - 326.

BABINA, G.V., BELYAKOVA, L.I. \& FILATOVA, Yu.O., (Eds.), 2008. Innovacionnoe soderzhanie vysshego professional'nogo obrazovaniya $v$ logopedia. Moskva: Prometheus. [In Russian].

IVANOVA, G.E., et al., 2018. Organizacionnye aspekty obespecheniya vosstanovleniya psihicheskoj deyatel'nosti v processe nejroreabilitacii. Vestnik vosstanovitel'noj mediciny-Bulletin of Restorative Medicine. 2(84), 37 - 40. [In Russian].

IVANOVA, G.E., et al., 2018. Kak organizovat' medicinskuyu reabilitaciyu? Vestnik vosstanovitel'noj mediciny-Bulletin of Restorative Medicine. 2(84), 2 - 12. [In Russian].

FILATOVA, Yu.O., 2008. Innovacionnye aspekty podgotovki logopedov XXI veka. Prepodavatel' XXI vek-Teacher XXI century, 3, $20-26$. [In Russian].

GEORGIEVA, D. \& STOILOVA, R., 2021. Medical Speech-Language Pathology in Bulgaria - a Comparative Study of the Current Status and Development. Journal for ReAttach Therapy and Developmental Diversities [online]. Available from: doi.org/10.26407/2021jrtdd.1.41

GEORGIEVA, D., WOZNIAK, T., TOPBASH, S., VITASKOVA, K., VUKOVIC, M., ZEMVA, N. \& DURANOVIC, M., 2014. Education of Speech Language Therapists in some Central and Southeast European Countries. Folia Phoniatrica et Logopaedica. 66(4-5), 183 - 196.

LYAPIDEVSKY, S.S., 1959. Osnovy nevropatologii. Moskva: Education. [in Russian].

Order of the Ministry of Education and Science of the Russian Federation of February 22, 2018 N 121 "On Approval of the Federal State Educational Standard of Higher Education - Bachelor's Degree in the field of training 03.04.01 Pedagogical Education”.

Order of the Ministry of Education and Science of the Russian Federation of February 22, 2018 N 126 "On the approval of the federal state educational standard of higher education - Master's degree in the field of training 04.04.01 Pedagogical education".

ORLIKOFF, R.F. \& GEORGIEVA, D., 2021. Promoting the Internationalization of Speech-Language Pathology Education: The 
Bulgarian-American Cooperative Experience. Strategies for Policy in Science and Education-Strategii na Obrazovatelnata i Nauchnata Politika. 29(2), $172-184$.

SLASTENIN, V.A., 2000. Slastenin. Moskva: Ed. house MAGISTRPRESS. [in Russian].

World Health Organization, 2001. International Classification of Functioning, Disability, and Health (ICF). https://www.who.int/ standards/classifications/international-classification-of-functioningdisability-and-health

Anna A. Almazova

Doctor in Education, Head of the Speech \& Language Therapy Department

Director of the Institute of Childhood ORCID iD: 0000-0002-7042-6037

Scopus ID: 57201726878

RSCI ID: 258565

Moscow Pedagogical State University (MPSU)

127224 Moscow, Russia

E-mail: aa.almazova@mpgu.su

$\triangle$ Yulia O. Filatova

Doctor in Education, Professor of the Speech \& Language Therapy Department

Director of Scientific Center of Interdisciplinary Research in Special and Inclusive Education (SCIRSIE) of the Institute of Childhood ORCID iD: 0000-0003-2890-3722

Researcher ID: 10334808

Moscow Pedagogical State University (MPSU)

119602 Moscow, Russia

E-mail: yuo.filatova@mpgu.su

Irina V. Novitskaia

Senior Lecturer, Foreign Languages at Primary School Department Institute of Childhood

ORCID iD: 0000-0002-5734-5208

Moscow Pedagogical State University (MPSU)

142412 Moscow, Russia

E-mail: iv.novitckaya@mpgu.su 